\title{
Effect of Cathodic Polarization on Corrosion Behavior of X65 Steel in Seawater Containing Iron-oxidizing Bacteria
}

\author{
Meiying Lv, Yongyong Yue, Zhenxin Li, Min Du* \\ Key Laboratory of Marine Chemistry Theory and Technology, Ministry of Education, College of \\ Chemistry and Chemical Engineering, Ocean University of China, Qingdao 266100, P.R. China \\ *E-mail: ssdm99@ouc.edu.cn
}

doi: $10.20964 / 2021.01 .42$

Received: 8 September 2020 / Accepted: 30 October 2020 / Published: 30 November 2020

\begin{abstract}
Microbiologically influenced corrosion is mainly caused by the biological activity in the biofilm, which clearly illustrates the role of attached bacteria in the form of biofilm in initiating or accelerating corrosion. Although it has been proven that electrochemical methods can prevent the formation of biofilms on metal surfaces, the special effect of cathodic polarization in bacterial attachment and growth is still inconclusive. The purpose of this work was to investigate the effect of cathodic polarization on the attachment of iron-oxidizing bacteria (IOB) in seawater during the initial stage of biofilm formation. Results showed that under the polarization potential of $-1050 \mathrm{mV}$ vs. SCE, IOB attachment and biofilm growth were well controlled. Further, the potential of $-1050 \mathrm{mV}$ vs. SCE exhibited more effective inhibitory effect on IOB-induced pitting corrosion than that of $-700 \mathrm{mV}$ vs. SCE, which was related to the accumulation of electrons on the metal surface during cathodic polarization. The cathodic potential of $-1050 \mathrm{mV}$ vs. SCE also altered the electrochemical parameters at the metal-biofilm interface, such as the increase of $\mathrm{pH}$ and the formation of protective calcareous deposits, which contributed to protect the metal from IOB-induced corrosion.
\end{abstract}

Keywords: Microbiologically influenced corrosion; Cathodic polarization; Iron-oxidizing bacteria; Bacterial attachment; Biofilm

\section{FULL TEXT}

(C) 2021 The Authors. Published by ESG (www.electrochemsci.org). This article is an open access article distributed under the terms and conditions of the Creative Commons Attribution license (http://creativecommons.org/licenses/by/4.0/). 